\title{
Nitrogen, potash and magnesium nutrition of some vegetable fruit crops under glass
}

\author{
C. Sonneveld and S. J. Voogt \\ Glasshouse Crops Research Station, Naaldwijk, the Netherlands
}

Accepted: 19 December 1980

Key words: fertilization, vegetable fruit crops, glasshouse, soil testing, nutrient uptake

\section{Summary}

In a long-term experiment, the effects of the application of nitrogen, potassium and magnesium to the irrigation water were studied on several fruit crops under glass. Besides different proportions of the nutrient elements mentioned, the investigation was concerned particularly with the concentration of the nutrient elements in the irrigation water. The effects of the base dressing were also included in the experiments. The water was applied to the crops with the aid of strip irrigation spray lines. The nutrient status of the soil was checked regularly by soil analyses by using the $1: 2$ volume extract method.

The yield data showed that the fertilizer containing $9 \mathrm{~mol} \mathrm{~N}, 4 \mathrm{~mol} \mathrm{~K}$ and $1.6 \mathrm{~mol}$ $\mathrm{Mg} \mathrm{kg}^{-1}$ generally produced the highest yields when applied at rates of 0.45 to 0.90

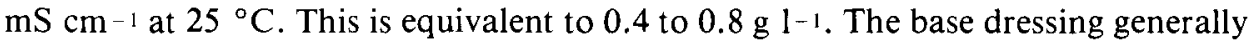
had little effect on the yields of the various crops.

In a discussion, standards are given for the levels of soil analytical data obtained with the aid of the $1: 2$ volume extract and the saturation extract. The relationship between liquid feeding at a rate of $0.9 \mathrm{mS} \mathrm{cm}^{-1}$ and the nutrient uptake of various crops was established by means of calculations.

\section{Introduction}

Glasshouse crops in the Netherlands are usually given supplementary feeds by adding fertilizers to the irrigation water with the aid of concentration meters (Sonneveld \& van den Ende, 1967). The meter provides accurate control over the concentration of the fertilizers in the irrigation water by monitoring the electrical conductivity (EC) of the enriched water. Maintaining the correct fertilizer dosage is important if the highest possible yields are to be obtained with economy in fertilizer usage.

In order to obtain more information on liquid feeding of some glasshouse vegeta- 
ble fruit crops, an experiment was started at the Research Station at Naaldwijk in 1973 , in which several aspects of fertilizer applications to the irrigation water were studied. Experimental crops of tomatoes, cucumbers, sweet peppers and aubergines were grown during seven successive years. The investigation was concerned particularly with the nitrogen, potash and magnesium nutrition of these crops.

\section{Methods and materials}

Experimental design

The following three factors were included in the experiment.

\section{Factor a. Fertilizers}

A $9.0 \mathrm{~mol} \mathrm{~N}, 4.0 \mathrm{~mol} \mathrm{~K}, 1.6 \mathrm{~mol} \mathrm{Mg}, 1.6 \mathrm{~mol} \mathrm{~S} \mathrm{~kg}^{-1}$

B $10.0 \mathrm{~mol} \mathrm{~N}, 2.5 \mathrm{~mol} \mathrm{~K}, 1.8 \mathrm{~mol} \mathrm{Mg}, 1.8 \mathrm{~mol} \mathrm{~S} \mathrm{~kg}^{-1}$

C $16.0 \mathrm{~mol} \mathrm{~N}, 3.3 \mathrm{~mol} \mathrm{~K} .3 .0 \mathrm{~mol} \mathrm{~S} \mathrm{kg-1}$

Factor b. Concentration (EC in $\mathrm{mS} \mathrm{cm}^{-1}$ at $25^{\circ} \mathrm{C}$ )

10.45

20.90

$\begin{array}{ll}3 & 1.35\end{array}$

$4 \quad 1.80$

\section{Factor c. Base dressing}

1 none

2 rather low

3 normal

4 rather high

The experiment consisted of 48 treatments which were carried out in triplicate. The treatments resulting from the combinations of factors $a$ and $b$ were located in $a$ main design in a randomised block. Factor $c$ was distributed as a split plot schema in the main design.

The fertilizers A and B were prepared from $\mathrm{KNO}_{3}, \mathrm{NH}_{4} \mathrm{NO}_{3}$ and $\mathrm{MgSO}_{4} \cdot 7 \mathrm{H}_{2} \mathrm{O}$. Fertilizer $\mathrm{C}$ was prepared from $\mathrm{KNO}_{3}, \mathrm{NH}_{4} \mathrm{NO}_{3}$ and $\left(\mathrm{NH}_{4}\right)_{2} \mathrm{SO}_{4}$. In addition to nitrogen, potassium and magnesium, the fertilizers also contained sulphate. The mixtures mentioned under $a$ show that the amount of sulphate is in a more or less constant ratio to the amount of nitrogen. The sulphate was used as the balancing item in the fertilizer ion composition. For the nutrition of the crops it was present in excess and for this reason it will be ignored in considering the experimental results. The fertilizer ratios $\mathrm{mol} \mathrm{NH}_{4}{ }^{+}:$mol $\mathrm{NO}_{3}{ }^{-}$varied largely and were $1: 2.6,1: 1.7$ and $1: 0.7$ for $\mathrm{A}, \mathrm{B}$ and $\mathrm{C}$ respectively. The $\mathrm{EC}$ values for these fertilizers* were 1.10 , 1.08 and $1.65 \mathrm{mS} \mathrm{g}^{-1} 1$ respectively.

\footnotetext{
* This indicates the increase in EC of a solution of the fertilizers for each $\mathrm{g} \mathrm{I}^{-1}$.
} 
For the base dressings, different amounts of nitrogen, potassium and magnesium were applied. The amounts of sulphate also varied as a result of the choise of fertilizers. The amounts applied were adjusted according to the nutrient levels present in the soil and the crops to be grown. The 'normal' level is the one considered as opti$\mathrm{mal}$ in the Dutch glasshouse industry. The 'rather low' level was achieved by applying $50 \%$ less fertilizer than for the normal level and the 'rather high' level was achieved by applying $50 \%$ more fertilizer. For some crops there were no differences in base dressings.

\section{Growing conditions}

The experiments were carried out in a so-called Venlo glasshouse block equipped with pipe heating designed for very early cropping. The soil type in the glasshouse was light loam with a $\mathrm{pH}$ of about 6.5 and containing about $5 \%$ organic matter, $7 \%$ clay (particles $<2 \mu \mathrm{m}$ ) and 0.5 calcium carbonate.

In some years, two successive crops were grown and in other years only one. Table 1 list the crops grown together with their growing perids.

Water was applied with the aid of a strip splinking irrigation installation, i.e. an irrigation system which only wets the strips in which the crops are growing. The amount of water applied in the course of a year varied from 500 to $800 \mathrm{~mm}$. On some occasions the soil was flooded after the crop had been cleared, for which purpose about $100 \mathrm{~mm}$ water was applied. The irrigation water was of very good quality. The EC was usually around $0.2 \mathrm{mS} \mathrm{cm}^{-1}$ at $25^{\circ} \mathrm{C}$ and the chloride content between 0.5 and $1.0 \mathrm{~mol}^{-1}$.

When it was considered necessary, soil sterilization was carried out by steaming or by treatment with methyl bromide. The soil structure was maintained by incorporating farmyard manure. Lime was applied only once during the years of the experiments and the same amounts were applied to all the treatments, i.e. $30 \mathrm{~kg}$ ground calcium-magnesium lime stone per $100 \mathrm{~m}^{2}$.

\section{Base dressings}

As already mentioned, the base dressings were matched to the nutrient status of the soil and the crop to be grown. There were no variations in the base dressings in the

Table 1. Experimental crops grown.

\begin{tabular}{lll}
\hline Crop & Year & Cropping period \\
Cucumbers & 1973 & July to October \\
Sweet peppers & 1974 & March to December \\
Tomatoes & 1975 & June to November \\
Cucumbers & 1976 & January to June \\
Sweet peppers & 1976 & July to November \\
Tomatoes & 1977 & January to July \\
Cucumbers & 1977 & August to October \\
Aubergines & 1978 & January to October \\
Tomatoes & 1979 & January to June \\
\hline
\end{tabular}


case of two crops, the sweet pepper crop in 1976 and the tomato crop in 1979. The 'rather high' levels of base dressings applied to the various crops consisted on average of $2.0 \mathrm{~mol} \mathrm{~N}, 0.7 \mathrm{~mol} \mathrm{~K}$ and $0.4 \mathrm{~mol} \mathrm{Mg} \mathrm{per} \mathrm{m}^{2}$. For the 'normal' and 'rather low' levels, two-third and one-third of these amounts were applied. The base dressings were generally watered in after application.

\section{Soil analyses}

The soil was sampled and analysed at regular intervals during the cropping periods. The samples were collected from a depth of $25 \mathrm{~cm}$ from the strips which were irrigated. The samples were analysed by means of aqueous extracts with the $1: 2$ volume extract method (Sonneveld \& van den Ende, 1971). The following determinations were made: electrical conductivity $(\mathrm{EC})$, nitrogen $(\mathrm{N})$, potassium $(\mathrm{K})$ and magnesium $(\mathrm{Mg})$.

On some occasions the $\mathrm{pH}$ was also determined in a $1: 5$ soil-water suspension. For a description of the analytical methods used, the reader is referred to den Dekker \& van Dijk (1973). The EC was expressed as $\mathrm{mS} \mathrm{cm}^{-1}$ at $25^{\circ} \mathrm{C}$ and the contents of $\mathrm{N}, \mathrm{K}$ and $\mathrm{Mg}$ were expressed as $\mathrm{mmol} \mathrm{l}^{-1}$ of the extract.

\section{Results of the soil analyses}

The soil analysis data obtained showed a good reflection of the treatments applied. Table 2 list the average values for the 19 samplings performed. With regard to the analytical results obtained for the levels of factor $c$ - base dressings - a distinction was made in the sampling period, i.e. the first sample collected during the cropping period and samples collected at a later stage. The effects of the various base dressing treatments showed up better in the first than in the later samplings.

In order to express the relationship between the quantity of nutrient elements ap-

Table 2. Soil analytical data averaged over the factors in the experiments. EC expressed as $\mathrm{mS}^{\mathrm{cm}} \mathrm{c}^{-1}$ $\left(25^{\circ} \mathrm{C}\right.$ ) and $\mathrm{N}, \mathrm{K}$ and $\mathrm{Mg}$ as mmol $1^{-1}$ of the $1: 2$ volume extract.

\begin{tabular}{lllllllllll}
\hline Factor a & EC & $\mathrm{N}$ & $\mathrm{K}$ & $\mathrm{Mg}$ & Factor b & $\mathrm{EC}$ & $\mathrm{N}$ & $\mathrm{K}$ & $\mathrm{Mg}$ \\
$\mathrm{A}$ & 1.17 & 4.39 & 2.78 & 1.26 & 1 & & 0.99 & 3.13 & 1.41 & 0.86 \\
$\mathrm{~B}$ & 1.36 & 6.37 & 2.37 & 1.74 & 2 & & 1.22 & 4.54 & 1.99 & 1.17 \\
$\mathrm{C}$ & 1.44 & 6.62 & 2.35 & 1.21 & 3 & & 1.44 & 6.73 & 2.78 & 1.53 \\
& & & & & 4 & & 1.71 & 9.11 & 3.69 & 1.96 \\
\hline Factor c & Initial sampling & & & & Later sampling & & \\
& EC & $\mathrm{N}$ & $\mathrm{K}$ & $\mathrm{Mg}$ & $\mathrm{EC}$ & $\mathrm{N}$ & $\mathrm{K}$ & $\mathrm{Mg}$ \\
$\mathrm{a}$ & 1.16 & 4.70 & 2.47 & 1.12 & 1.31 & 5.41 & 2.22 & 1.43 \\
$\mathrm{~b}$ & 1.31 & 5.47 & 2.96 & 1.34 & 1.36 & 5.75 & 2.46 & 1.49 \\
$\mathrm{c}$ & 1.66 & 7.07 & 3.80 & 1.88 & 1.45 & 6.15 & 2.76 & 1.64 \\
$\mathrm{~d}$ & 1.90 & 8.17 & 4.50 & 2.20 & 1.52 & 6.25 & 2.86 & 1.71 \\
\hline
\end{tabular}


Table 3. The effects of the application of nutrients via the irrigation water (A) or directly to the soil (B) on the results of soil analyses.

\begin{tabular}{|c|c|c|c|}
\hline \multirow[t]{2}{*}{ Element } & \multirow[t]{2}{*}{ Quotient for $\mathrm{A}^{*}$} & \multicolumn{2}{|l|}{ Quotient for B* } \\
\hline & & initial sampling & later sampling \\
\hline$N$ & 0.49 & 1.8 & 0.4 \\
\hline K & 0.64 & 2.9 & 0.9 \\
\hline $\mathrm{Mg}$ & 0.79 & 3.0 & 0.8 \\
\hline
\end{tabular}

Table 4. The effects of application rates of different fertilizers on the $\mathrm{pH}$ of the soil.

\begin{tabular}{lllll}
\hline Fertilizer & \multicolumn{4}{l}{ Concentration } \\
\cline { 2 - 5 } & 1 & 2 & 3 & 4 \\
A & 6.9 & 6.8 & 6.7 & 6.5 \\
B & 6.8 & 6.7 & 6.4 & 6.3 \\
C & 6.7 & 6.3 & 6.0 & 5.8 \\
\hline
\end{tabular}

plied and its effect on the soil analysis figures, the quotients shown in Table 3 were calculated for the nutrient elements studied in these experiment. The quotients were obtained by calculating the regression equations for the relationships between the magnitudes referred to in the quotients. As the equations were linear, the quotients were equal to the regression coefficients of the equations. The few dressings of farmyard manure were not taken into account in the calculations. The farmyard manure was applied in equal quantities to all the treatments with the result that the nutrient status of the soil generally was enhanced slightly. The dressings had therefore no effect on the quotients calculated.

Although fertilizer $\mathrm{C}$ contained no magnesium, increasing magnesium contents were found in the $1: 2$ soil extract when the concentration of this fertilizer in the irrigation water was increases. A possible explanation is that the acid reaction of this fertilizer resulted in an accelerated release of magnesium carbonate in the soil. Table 4 shows that the application of fertilizer $\mathrm{C}$ caused a marked decrease in the $\mathrm{pH}$ caused by the high proportion of ammonium nitrogen in this fertilizer.

\section{Crop results}

\section{Yields}

The yields and the average fruit weights are shown in Tables 5 and 6 . The total of the produce harvested was used as the basis of the $\mathrm{kg}$ yield calculations, i.e. misshapen and small fruits were included. For the calculation of the average fruit weights, only the larger marketable fruits were used. 
Table 5. The yields of various crops in $\mathrm{kg} \mathrm{m}^{-2}$.

\begin{tabular}{|c|c|c|c|c|c|c|c|c|c|}
\hline \multirow[t]{2}{*}{ Factor } & \multicolumn{3}{|c|}{ Tomatoes } & \multicolumn{3}{|c|}{ Cucumbers } & \multicolumn{2}{|c|}{ Sweet peppers } & \multirow{2}{*}{$\frac{\text { Aubergines }}{1978}$} \\
\hline & 1975 & 1977 & 1979 & 1973 & 1976 & 1977 & 1974 & 1976 & \\
\hline$a$ & n.s. & n.s. & $* *$ & n.s. & * & n.s. & $* *$ & n.s. & n.s. \\
\hline A & 11.2 & 15.4 & 10.0 & 18.1 & 19.7 & 9.0 & 9.3 & 2.8 & 19.2 \\
\hline B & 11.0 & 15.0 & 9.4 & 17.8 & 17.6 & 9.0 & 9.5 & 2.5 & 18.4 \\
\hline $\mathrm{C}$ & 11.0 & 14.8 & 9.0 & 18.0 & 17.5 & 9.2 & 8.9 & 2.5 & 17.8 \\
\hline$b$ & n.s. & * & $* *$ & n.s. & n.s. & n.s. & \& & n.s. & $* *$ \\
\hline 1 & 10.9 & 15.6 & 10.0 & 18.5 & 19.0 & 9.4 & 9.5 & 2.5 & 20.2 \\
\hline 2 & 11.3 & 15.3 & 10.0 & 18.2 & 19.4 & 9.4 & 9.2 & 2.9 & 19.1 \\
\hline 3 & 11.2 & 15.0 & 9.4 & 17.8 & 17.8 & 8.8 & 9.1 & 2.6 & 18.0 \\
\hline 4 & 11.0 & 14.3 & 8.5 & 17.5 & 16.8 & 8.5 & 9.0 & 2.5 & 16.6 \\
\hline$c$ & n.s. & n.s. & & $*$ & n.s. & n.s. & $\%$ & & n.s. \\
\hline a & 10.8 & 15.2 & - & 18.3 & 18.9 & 9.2 & 8.9 & - & 18.9 \\
\hline b & 11.1 & 15.1 & - & 18.5 & 17.8 & 9.2 & 9.2 & - & 18.5 \\
\hline $\mathrm{c}$ & 11.2 & 14.9 & - & 17.6 & 18.7 & 8.9 & 9.1 & - & 18.4 \\
\hline $\mathrm{d}$ & 11.2 & 15.0 & - & 17.6 & 17.9 & 8.9 & 9.4 & - & 18.1 \\
\hline
\end{tabular}

${ }^{*} \mathrm{P}<0.05 ;{ }^{* *} \mathrm{P}<0.01 ;$ n.s. $\mathrm{P}>0.05$.

Table 6. Average weights in $\mathrm{g}$ of the marketable fruits of various crops.

\begin{tabular}{|c|c|c|c|c|c|c|c|c|c|}
\hline \multirow[t]{2}{*}{ Factor } & \multicolumn{3}{|c|}{ Tomatoes } & \multicolumn{3}{|c|}{ Cucumbers } & \multicolumn{2}{|c|}{ Sweet peppers } & \multirow{2}{*}{$\begin{array}{l}\text { Aubergines } \\
1978\end{array}$} \\
\hline & 1975 & 1977 & 1979 & 1973 & 1976 & 1977 & 1974 & 1976 & \\
\hline$a$ & n.s. & n.s. & n.s. & n.s. & n.s. & n.s. & $* *$ & n.s. & n.s. \\
\hline A & 60 & 73 & 59 & 569 & 444 & 412 & 124 & 188 & 313 \\
\hline B & 58 & 71 & 54 & 568 & 437 & 413 & 123 & 187 & 308 \\
\hline C & 59 & 72 & 55 & 564 & 435 & 412 & 121 & 192 & 306 \\
\hline$b$ & $* *$ & $* *$ & ** & ** & $* *$ & n.s. & $* *$ & $* *$ & ** \\
\hline 1 & 61 & 75 & 60 & 578 & 443 & 410 & 125 & 199 & 321 \\
\hline 2 & 61 & 72 & 59 & 567 & 446 & 412 & 123 & 191 & 313 \\
\hline 3 & 59 & 71 & 56 & 562 & 437 & 415 & 122 & 185 & 308 \\
\hline 4 & 56 & 68 & 49 & 561 & 428 & 413 & 119 & 181 & 294 \\
\hline$c$ & n.s. & n.s. & & n.s. & n.s. & * & n.s. & & n.s. \\
\hline a & 59 & 72 & - & 566 & 439 & 405 & 122 & - & 310 \\
\hline $\mathrm{b}$ & 60 & 72 & - & 569 & 436 & 411 & 124 & - & 309 \\
\hline c & 60 & 72 & - & 567 & 440 & 417 & 122 & - & 308 \\
\hline d & 60 & 72 & - & 566 & 439 & 417 & 122 & - & 309 \\
\hline
\end{tabular}

${ }^{*} \mathrm{P}<0.05 ;{ }^{* *} \mathrm{P}<0.01 ;$ n.s. $\mathrm{P}>0.05$.

On the whole, the yields were highest where fertilizer A was used and lowest where fertilizer $C$ was used. The yield differences between the fertilizers were caused sometimes by higher or lower fruit weights and sometimes by larger or smaller numbers of fruits harvested. 
With regard to the effects of fertilizer concentration in the irrigation water, it may be pointed out that yield were highest sometimes at $0.45 \mathrm{mS}$ and somtimes at 0.90 $\mathrm{mS}$. The yields generally decreased at higher concentrations, In the case of tomatoes, the yield reductions at 1.35 and $1.80 \mathrm{mS}$ were on average 3 and $8 \%$ respectively. In cucumbers the yield reductions were 5 and $9 \%$, in sweet peppers 4 and $6 \%$ and in aubergines 8 and $16 \%$. In tomatoes and sweet peppers, the yield reductions at higher fertilizer concentrations were caused mainly by reduced fruit weights. In cucumber, the differences in fruit weights were only small and in this case the yield reductions were the result of fewer fruits being produced. In aubergines, both the fruit weight and the number of fruits were affected by the higher fertilizer concentrations.

The base dressings hardly had any significant effect on the yields. The effects were sometimes slightly positive and sometimes slightly negative. The fruit weight was also hardly affected by the base dressings.

\section{Fruit quality}

In some crops, disorders were found in the fruit quality. This is shown in Table 7. In tomatoes, the incidence of uneven ripened fruit was reduced by increasing fertilizer concentrations in the irrigation water. However, the incidence of blossom end rot was increased. In sweet peppers too, there was a significant increase in the incidence of blossom end rot with increasing fertilizer concentrations. Increased base dressings also proved to encourage the incidence of blossom end rot in sweet peppers. In cucumbers, the fertilizer concentration had an effect on fruit colour. Increasing concentrations resulted in a darker fruit colour.

Table 7. Effects on fruit quality.

\begin{tabular}{|c|c|c|c|c|c|c|c|c|c|c|c|c|c|c|c|}
\hline \multicolumn{7}{|c|}{$\begin{array}{l}\text { Tomatoes } 1975: \\
\% \text { uneven ripened }\end{array}$} & \multicolumn{4}{|c|}{$\begin{array}{l}\text { Tomatoes 1979: } \\
\% \text { blossom end rot }\end{array}$} & \multicolumn{5}{|c|}{$\begin{array}{l}\text { Cucumbers 1973: } \\
\text { colour index* (I) }\end{array}$} \\
\hline$a$ & $\%$ & $b$ & \multicolumn{2}{|c|}{$\%$} & $c$ & $\%$ & $a$ & $\%$ & $b$ & $\%$ & $a$ & & & $b$ & I \\
\hline A & 0.4 & 1 & \multicolumn{2}{|c|}{0.7} & $a$ & 0.4 & A & 0.24 & 1 & 0.10 & A & \multicolumn{2}{|c|}{7.2} & 1 & 6.3 \\
\hline B & 0.3 & 2 & \multicolumn{2}{|c|}{0.4} & $\mathrm{~b}$ & 0.4 & B & 0.93 & 2 & 0.16 & B & \multicolumn{2}{|c|}{7.4} & 2 & - \\
\hline $\mathrm{C}$ & 0.4 & 3 & \multicolumn{2}{|c|}{0.2} & $c$ & 0.3 & C & 0.49 & 3 & 0.56 & C & \multicolumn{2}{|c|}{6.9} & 3 & - \\
\hline & & 4 & \multicolumn{2}{|c|}{0.1} & $\mathrm{~d}$ & 0.3 & & & 4 & 1.38 & & & & 4 & 8.0 \\
\hline \multicolumn{6}{|c|}{$\begin{array}{l}\text { Cucumbers 1976: } \\
\text { colour indes* (1) }\end{array}$} & \multicolumn{6}{|c|}{$\begin{array}{l}\text { Sweet peppers } 1974 \text { : } \\
\% \text { blossom end rot }\end{array}$} & \multicolumn{4}{|c|}{$\begin{array}{l}\text { Sweet peppers } 1976 \text { : } \\
\% \text { blossom end rot }\end{array}$} \\
\hline$a$ & 1 & $b$ & I & $c$ & I & $a$ & $\%$ & $\bar{b}$ & $\%$ & $c$ & $\%$ & $a$ & $\%$ & $b$ & $\%$ \\
\hline A & 6.9 & 1 & 6.5 & $\mathrm{a}$ & 7.2 & A & 3.1 & 1 & 2.2 & a & 2.2 & $\mathrm{~A}$ & 2.5 & 1 & 1.3 \\
\hline B & 7.3 & 2 & 7.1 & $b$ & 7.2 & B & 4.0 & 2 & 2.7 & b & 2.7 & B & 5.4 & 2 & 1.4 \\
\hline \multirow[t]{2}{*}{$\mathrm{C}$} & 7.2 & 3 & 7.4 & $\mathrm{c}$ & 7.0 & $\mathrm{C}$ & 4.2 & 3 & 3.9 & $\mathrm{c}$ & 4.6 & $\mathrm{C}$ & 5.6 & 3 & 5.6 \\
\hline & & 4 & 7.6 & $\mathrm{~d}$ & 7.2 & & & 4 & 6.2 & $\mathrm{~d}$ & 5.6 & & & 4 & 9.3 \\
\hline
\end{tabular}

* Higher figures denote darker colour.

Neth. J. agric. Sci. 29 (1981) 


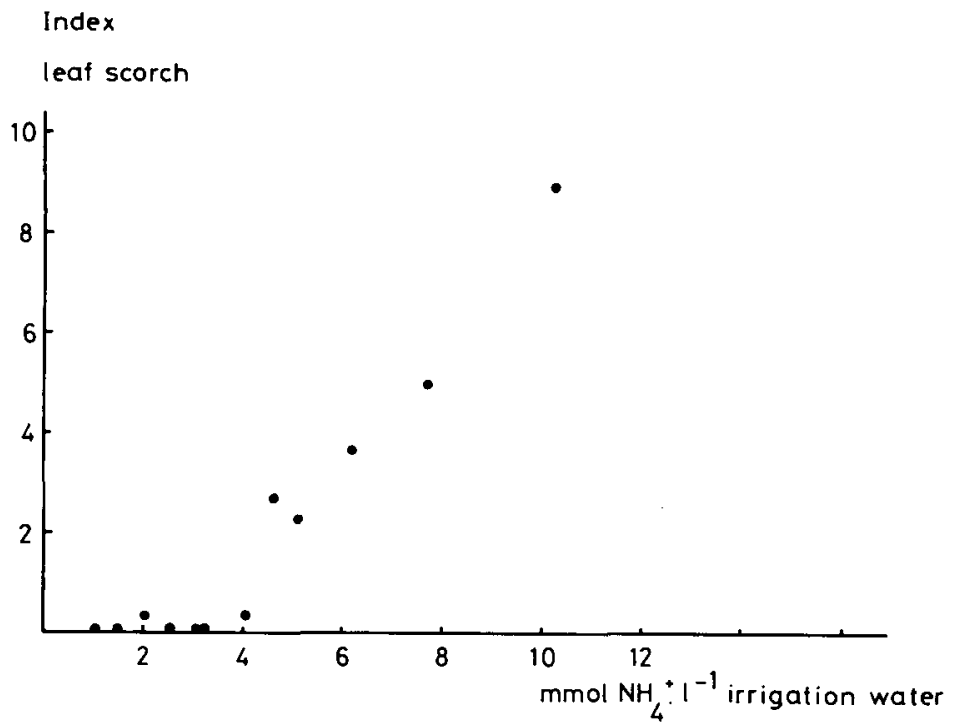

Fig. 1 The relationship between the ammonium content of the irrigation water and the incidence of leaf scorch in tomatoes. Index: $0=$ no leaf scorch and $10=$ severe leaf scorch.

\section{Crop growth}

Apart from the yield differences, variations in plant development were also often observed in the experiments. These symptoms became visible particularly in the early stages of the crop. The young plants showed a significantly darker colour and a more compact growth, the more fertilizers were added to the soil. These effects were observed irrespective of whether the fertilizers were added via the irrigation water or in the form of the base dressing.

Leaf scorch occurred sometimes in the early stages of the crop when the leaves came into contact with the irrigation water. This occurred particularly where fertilizer $C$ was used which may be attributed to the high ammnium content in this fertilizer which is known to readily cause leaf scorch (Sonneveld \& van den Ende, 1967). Fig. 1 illustrates the relationship between the ammonium concentration of the irrigation water and the incidence of lear scorch observed in a tomato crop in 1979. There was hardly any leaf scorch when concentrations of up to $4 \mathrm{mmol} \mathrm{NH}_{4}^{+} 1^{-1}$ were used. At higher concentrations the leaf scorch symptoms increased linearly with the ammonium concentration.

\section{Discussion}

In the application of nitrogen, potassium and magnesium to the irrigation water for use on fruit crops under glass, the highest yields were obtained with concentration equivalent to electrical conductivities between 0.45 and $0.90 \mathrm{mS} \mathrm{cm}^{-1}$ at $25{ }^{\circ} \mathrm{C}$, The fertilizer with contents of $9 \mathrm{~mol} \mathrm{~N}, 4 \mathrm{~mol} \mathrm{~K}$ and $1.6 \mathrm{~mol} \mathrm{Mg} \mathrm{kg}^{-1}$ produced slightly 
higher yields on the whole than the fertilizer which contained less potassium relative to nitrogen or the fertilizer which contained relatively less potassium and no magnesium.

Increasing fertilizer rates generally resulted in yield reductions as well as quality defects such as blossom end rot in tomatoes and sweet peppers. This disorder is caused by calcium deficiency in the fruits. High rates of fertilizers may impede the uptake of calcium and its transport to the fruits, resulting in blossom end rot. Apart from the negative effects on the fruit quality of some crops, high fertilizer rates may also have positive effects such as improved colour in tomatoes and the darker colour of cucumber fruits. In the case of cucumbers this results in a better storage quality (van Esch, 1980a and b).

In some cases, a higher fertilizer level also proved to have a beneficial effect on the development of the plants. The darker leaf colour and more compact growth resulting from higher fertilizer levels are particularly important for crops such as tomatoes which tend to have strong vegetative growth in the early stages of the crop. For this reason, the application of a base dressing may be beneficial even though in most cases there was no significant effect on the yields in these experiments.

On the basis of the experimental data as well as practical experience, the highest rate of base dressing included in these experiments may be regarded as beneficial for tomatoes. This is certainly the case where the crop is started under poor light conditions. For other fruit crops under glass half the base dressing rat mentioned would be sufficient.

For liquid feeding via the irrigation water, the fertilizer containing $9 \mathrm{~mol} \mathrm{~N}, 4 \mathrm{~mol}$ $\mathrm{K}$ and $1.6 \mathrm{~mol} \mathrm{Mg} \mathrm{kg}{ }^{-1}$ proved to be most satisfactory on the whole. A conductivity of $0.90 \mathrm{mS} \mathrm{cm}^{-1}$ at $25^{\circ} \mathrm{C}$ could be regarded as more or less optimal. Although 0.45 $\mathrm{mS} \mathrm{cm}{ }^{-1}$ resulted in similar yields, crops under glass should not be grown at low fertilizer rates as experience has shown that low soil concentrations tend to give rise to problems in fruit quality.

With the fertilizer rate mentioned as the starting point, it becomes possible to calculate the optimum values for $\mathrm{N}, \mathrm{K}$ and $\mathrm{Mg}$ contents in the $1: 2$ volume extract with the aid of the quotients listed in Table 3 . If the base dressing mentioned previously had to be taken into account, it will be necessary to calculate two values, one for the initial stages of the crop and one for the later stages when the base dressing hardly had any effect any more on the contents in the soil. The results of the calculations based on the starting points mentioned are as follows:

\begin{tabular}{llll} 
Element & \multicolumn{2}{l}{ Initial stage } & Later stage \\
\cline { 2 - 3 } & tomatoes & other crops & \\
$\mathrm{N}$ & 7.2 & 5.4 & 3.6 \\
$\mathrm{~K}$ & 4.2 & 3.1 & 2.1 \\
$\mathrm{Mg}$ & 2.2 & 1.6 & 1.0
\end{tabular}

The analytical results of the $1: 2$ volume extract are closely correlated with those of the saturation extract (Sonneveld \& van der Ende, 1971). It is therefore possible to transpose the analytical results mentioned to the saturation extract by using a mul- 
Table 8. The uptake of nitrogen, potassium and magnesium calculated from the literature and expressed as mmol kg-1 produce harvested and as mol m-2 at a certain level of production.

\begin{tabular}{lrrl}
\hline & \multicolumn{2}{l}{ Uptake in mol $\mathrm{kg}^{-1}$ produce } & Uptake in $\mathrm{mol} \mathrm{m}^{-2}$ \\
\cline { 2 - 3 } Tomatoes & range & average & \\
$\mathrm{N}$ & & & at $25 \mathrm{~kg} \mathrm{per} \mathrm{m}^{2}$ \\
$\mathrm{~K}$ & $129-220$ & 157 & 3.92 \\
$\mathrm{Mg}$ & $79-146$ & 106 & 2.65 \\
& $9-23$ & 14 & 0.35 \\
Cucumbers & & & \\
$\mathrm{N}$ & $104-154$ & 126 & at $50 \mathrm{~kg} \mathrm{per} \mathrm{m}^{2}$ \\
$\mathrm{~K}$ & $54-71$ & 60 & 6.30 \\
$\mathrm{Mg}$ & $10-16$ & 14 & 3.00 \\
\hline
\end{tabular}

tiplication factor of 3 for nitrogen, 2 for potassium and 2.5 for magnesium.

Data reported by Spithost (1959), Hamaker \& van der Burg (1978, 1979), Ward (1967) and Spensley et al. (1978) made it possible to calculate the uptake of nitrogen, potassium and magnesium by tomato crops. The uptake of these elements by cucumbers could also be calculated with data reported by Roorda van Eysinga (1964), Hamaker \& van der Burg (1978) and Ward (1967). In collecting these data it was noted that German literature mentions a much higher potassium uptake by cucumbers relative to the nitrogen uptake (Laske, 1979). These data were omitted as they were probably the result of luxury consumption.

The uptake of the elements mentioned is expressed as mmol kg-1 of the produce harvested. Table 8 shows the ranges and averages of the values found, whilst the last column shows the uptake data calculated for tomatoes and cucumbers for production levels of 25 and $50 \mathrm{~kg} \mathrm{~m}^{-2}$. These production levels are perhaps high, but they are not exceptional in the Netherlands. The amounts of water applied to long-term tomato and cucumber crops are estaimated at 750 and $900 \mathrm{~mm}$ respectively (Van der Post et al. 1974). The concentrations of nitrogen, potassium and magnesium taken up by the crop, expressed over the quantity of water used, are listed in Table 9. The last column of this table shows the nutrient concentrations obtained at an application rate of $0.9 \mathrm{mS} \mathrm{cm}^{-1}$ of fertilizer $\mathrm{A}$.

The uptake of nitrogen and potassium by cucumbers shows a close relationship

Table 9. The uptake of nitrogen, potassium and magnesium by tomatoes and cucumbers expressed over the water consumption of these crops and an application rate of $0.90 \mathrm{mS} \mathrm{cm}^{-1}$ of fertilizer $\mathrm{A}$.

\begin{tabular}{llll} 
& \multicolumn{2}{l}{ Uptake in mmol ${ }^{-1}$} & Application rate in mmol $1^{-1}$ \\
\cline { 2 - 3 } & tomatoes & cucumbers & \\
$\mathrm{N}$ & 5.23 & 7.00 & 7.36 \\
$\mathrm{~K}$ & 3.53 & 3.33 & 3.27 \\
$\mathrm{Mg}$ & 0.47 & 0.78 & 1.31 \\
\hline
\end{tabular}


with the supply data mentioned. For tomatoes, a fertilizer containing a little more potassium and less nitrogen might be desirable. Magnesium is applied in larger amounts than are taken up by the crop, but this may be necessary as this element often is taken up less readily by the crop. The base dressings have not been taken into account in these deliberations. In the case of cucumbers, the base dressing mentioned previously amounts to only 10 to $15 \%$ of the fertilizer rates calculated in Table 9 . However, the higher base dressing for tomatoes amounts to 30 to $40 \%$ of the rate calculated in Table 9 . It may therefore be necessary to reduce the fertilizer concentration in the irrigation water temporarily when the first trusses are set and the nutrient status of the soil may be reduced.

With regard to sweet peppers and aubergines, the data concerning the nutrient uptake are less accurately known than they are for tomatoes and cucumbers. The results of crop analyses indicate that the relationship between the uptake of nitrogen and potassium by sweet peppers is similar to that for tomatoes, whilst for aubergines, the relationship resembles that for cucumbers (Sonneveld, 1979).

\section{References}

Dekker, P. A. den en P. A. van Dijk, 1973. Analysemethoden in gebruik op het bodemkundig laboratorium van het Proefstation voor Tuinbouw onder Glas te Naaldwijk (not published).

Esch, H. G. A. van, 1980a. Komkommers. Vaker oogsten geeft langere houdbaarheid. Groenten en Fruit 35(37)41-43.

Esch, H. G. A. van, 1980b. Nachttemperatuur en houdbaarheid van komkommers. Groenten en Fruit 35(37)48-49.

Hamaker, Ph. \& A. A. M. van der Burg, 1978. De water-en mineralenbalans van een glastuinbouwbedrijf in de periode 1976/77. Instituut voor Cultuurtechniek en Waterhuishouding, Wageningen. Nota 1072.

Hamaker, Ph. \& A. A. M. van der Burg, 1979. De water- en mineralenhuishouding van een glastuinbouwbedrijf op een zandgrond in het Westland in de periode 1977/78. Instituut voor Cultuurtechniek en Waterhuishouding, Wageningen. Nota 1129.

Laske, P., 1979. Erhebungsuntersuchungen zum Verlauf der Nährstoffaufnahme einer Hausgurkenkultur. Bodenkultur 30: 7-20.

Post, C. J. van der, J. J. van Schie \& R. de Graaf, 1974. Energy balance and water supply in glasshouses in West-Netherlands. Acta Hort. 35: 13-22.

Roorda van Eysinga, J. P. N. L. \& J. N. M. van Haeff, 1964. Onttrekking van voedingselementen aan de grond door komkommer. Proefstation voor de Groenten en Fruitteelt onder Glas te Naaldwijk, Jaarverslag 1964: 35-38.

Sonneveld, C. \& J. van den Ende, 1967. Bijmesten via de regenleiding met behulp van de concentratiemeter. Meded. Dir. Tuinb. 30: 54-60.

Sonneveld, C. \& J. van den Ende, 1971. Soil analysis by means of a $1: 2$ volume extract. Plant Soil, 35: 505-516.

Sonneveld, C., 1979. Effects of salinity on the growth and mineral composition of sweet pepper and egg plant grown under glass. Acta Hort. 89: 71-78.

Spensley, K., G. W. Winsor and A. J. Cooper, 1978. Nutrient film technique - crop culture in flowing nutrient solution. Outlook Agriculture 9: 299-305.

Spithorst, L. S., 1959. De onttrekking aan de grond van minerale voedingsstoffen door de tomaat. Proefstation voor de Groenten en Fruitteelt onder Glas te Naaldwijk, Jaarverslag, 1959: $29-31$.

Ward, G. M., 1967. Growth and nutrient absorption in greenhouse tomato and cucumber. Proc. Am Soc. hort. Sci. 90: 335-341. 